\title{
PENGARUH PADAT TEBAR TERHADAP KANDUNGAN ZAT GIZI IKAN LELE YANG DIPELIHARA DENGAN TEKNOLOGI BIOFLOK
}

\author{
Anang Suhardianto \\ Ariyanti Hartari \\ Fakultas Sains dan Teknologi, Universitas Terbuka \\ E-mail: anang@ecampus.ut.ac.id
}

\begin{abstract}
This study aims to determine the effect of stocking density on the nutrient content of catfish that is cared with biofloc technology. Nutrients observed: 1) water content, 2) protein, 3) carbohydrates, 4) total fat, 5) saturated fatty acids / SFA, 6) monounsaturated fatty acids/ MUFA, 7) plural unsaturated fatty acids / PUFA , 8) omega-3, 9) omega-6, and 10) omega 9. Statistical tests on the 10 variables showed that stocking density did not have a significant effect on the 10 variables at a 5\% confidence interval. Stocking density of treatment is 1000 heads/pond (T1), 2000 heads/pond (T2), 3000 heads/pond (T3), with a pond size of $2.0 \mathrm{mx}$ height $1.0 \mathrm{~m}$. Research results: 1 . The average water content is $69,40-71,47 \%$ and the highest T3. 2. The protein content is $14,70-15,90 \%$, the highest T2. 3. Carbohydrate content of $5,16-5,50 \%$, the highest T2. 4. The average total fat content of $6,73-7.78 \%$, the highest T1. 5. SFA content is around $43 \%$, PUFA around $23 \%$, and MUFA around $32 \% .6$. The highest omega- 3 content is T3, then T1, and T2. Omega- 6 and 9 sequence contents are $T 1$, $T 2$, and T3. It was concluded, the treatment of biofloc catfish stocking densities at a 5\% confidence interval did not have a significant effect on the specified nutrient content.
\end{abstract}

Keywords: biofloc technology, floc, catfish

\begin{abstract}
ABSTRAK
Penelitian ini bertujuan untuk menentukan pengaruh padat tebar terhadap kandungan zat gizi ikan lele yang dipelihara dengan teknologi bioflok. Zat gizi yang diamati: 1) kandungan air, 2) protein, 3) karbohidrat, 4) lemak total, 5) asam lemak jenuh/SFA, 6) asam lemak tak jenuh tunggal/MUFA, 7) asam lemak tak jenuh jamak/PUFA, 8) omega-3, 9) omega 6, dan 10) omega 9. Uji statistik terhadap ke-10 variabel menunjukkan padat tebar tidak memberikan pengaruh nyata terhadap ke-10 variabel pada selang kepercayaan $5 \%$. Padat tebar perlakuan adalah 1000 ekor/kolam (T1), 2000 ekor/kolam (T2), 3000 ekor/kolam (T3), dengan ukuran kolam diameter 2,0 $\mathrm{m}$ x tinggi 1,0 m. Hasil penelitian: 1. Rata-rata kandungan air $69,40-71,47 \%$ dan T3 tertinggi. 2 . Kandungan protein $14,70-15,90 \%$, T2 tertinggi. 3. Kandungan karbohidrat 5,16-5,50\%, T2 tertinggi. 4. Rata-rata kandungan lemak total $6,73-7,98 \%$, T1 tertinggi. 5. Kandungan SFA sekitar 43\%, PUFA sekitar 23\%, dan MUFA sekitar 32\%. 6. Kandungan omega-3 tertinggi T3, kemudian T1, dan T2. Omega-6 dan 9 urutan kandungannya T1, T2, dan T3. Disimpulkan, perlakuan padat tebar lele bioflok pada selang kepercayaan $5 \%$ tidak memberikan pengaruh yang nyata terhadap kandungan zat gizi yang ditentukan.
\end{abstract}

Kata kunci: teknologi bioflok, flok, ikan lele 
Dengan melambungnya harga daging sapi hingga mencapai harga lebih dari seratus ribu per kilogram membuat sebagian masyarakat Indonesia kehilangan akses terhadap salah satu sumber protein hewani. Untuk mengembalikan akses tersebut perlu dilakukan pencarian sumber protein hewani alternatif agar masyarakat bersedia berpindah dari daging sapi ke sumber protein hewani alternatif yang harganya lebih terjangkau. Dengan harga antara dua puluh hingga dua puluh lima ribu rupiah per kologram, ikan lele dapat dipertimbangkan sebagai sumber protein hewani alternatif.

Menurut Sari (2015), ikan lele merupakan pangan lokal yang mudah didapat dan harganya murah. Ikan lele adalah salah satu ikan air tawar yang paling banyak diminati serta dikonsumsi oleh masyarakat Indonesia dari berbagai lapisan. Harganya yang terjangkau membuat ikan lele terdistribusi secara merata hampir di seluruh pelosok tanah air. Dari segi zat gizi yang dikandungnya, Astawan (2008) mengungkapkan bahwa ikan lele mempunyai nilai protein yang sangat tinggi. Protein ikan adalah protein yang istimewa karena bukan hanya berfungsi sebagai penambah jumlah protein yang dikonsumsi, tetapi juga sebagai pelengkap mutu protein dalam menu makanan. Ikan lele mempunyai kandungan protein sekitar $17,7 \%$ dan lemak $4,8 \%$.

Budidaya ikan lele yang baik adalah dalam kolam dengan pakan bukan bersumber dari kotoran, baik kotoran hewan maupun manusia. Bagi ikan lele, pakan merupakan variabel yang paling berpengaruh terhadap kecepatan pertumbuhannya, makin banyak pakan makin cepat pertumbuhannya. Kondisi ini membuat petani ikan yang nakal kadang-kadang berbuat di luar batas etika dengan memberikan pakan berupa kotoran.

Mengingat posisi strategis dari pakan terhadap pertumbuhan ikan lele tersebut, petani ikan terus berusaha mencari teknologi yang mampu menekan jumlah pakan tanpa mengurangi kecepatan pertumbuhan ikan. Salah satu teknologi yang diadopsi oleh petani ikan, yang merupakan terobosan baru dalam bidang budidaya akuakultur, yaitu teknologi bioflok. Yuniartik, Hariati \& Fadjar (2015) mengemukakan bahwa telah terjadi efisiensi pakan yang lebih tinggi dalam sistem bioflok, yang kemudian menghasilkan biomassa udang yang tinggi saat panen. Efisiensi ini nampaknya terjadi karena bahan organik dari kelebihan pakan dan feses terdegradasi dan diubah menjadi protein in-situ dalam bentuk sel bakteri (bioflok) dan sebagian dikonsumsi oleh udang. Selain itu, dalam booklet Direktorat Usaha Budidaya, Direktorat Jenderal Perikanan Budidaya dikemukakan bahwa dengan teknologi ini petani dapat menekan penggunaan pakan hingga mencapai FCR (Feed Conversion Ratio) 0,7. Keuntungan lain teknologi bioflok, seperti: membutuhkan sedikit pergantian air (efisien dalam penggunaan air); tidak tergantung sinar matahari; padat tebar ikan lebih tinggi (bisa mencapai 3.000 ekor/m3); produktivitas tinggi; efisiens dalam pemanfaatan lahan; sedikit menghasilkan limbah; dan ramah lingkungan (Anonim, 2013).

Namun demikian arah kajian semua penelitian yang berkaitan dengan teknologi bioflok untuk ikan lele tersebut adalah pada budidayanya. Sejauh ini peneliti tidak atau belum menemukan penelitian yang mengulas komposisi zat gizi yang dikandung ikan lele yang pembesarannya dilakukan dengan menerapkan teknologi bioflok. Padahal tujuan akhir dari pembesaran ikan lele adalah untuk konsumsi manusia.

Meliala (2009) menyebutkan bahwa ikan merupakan salah satu bahan makanan yang mengandung berbagai macam zat gizi. Sebagai bahan pangan, ikan merupakan sumber protein, lemak, vitamin, dan mineral yang sangat baik dan prospektif. Keunggulan utama protein ikan dibandingkan dengan produk lainnya adalah kelengkapan komposisi asam amino dan kemudahannya untuk dicerna. Dengan alasan tersebut maka penelitian ini perlu dilakukan. Dengan 
penelitian ini, hasilnya akan melengkapi informasi ilmiah khususnya informasi yang berkaitan dengan penerapan teknologi bioflok pada budidaya akuakultur.

Besarnya kandungan zat gizi pada tubuh ikan sangat ditentukan oleh banyaknya pakan yang dikonsumsi ikan. Salah satu variabel yang menentukan kuantitas pakan yang dikonsumsi ikan adalah banyaknya (padat tebar) bibit ikan yang akan dibesarkan dalam kolam. Semakin padat (banyak) benih ikan yang dibesarkan akan semakin sedikit kuantitas pakan yang dikonsumsi ikan secara individu karena akan terjadi persaingan yang semakin ketat. Dengan memanfaatkan teknologi bioflok diharapkan pemenuhan gizi ikan akan tetap terjaga karena selain makan pakan buatan (pelet), ikan juga makan bioflok yang terbentuk selama pemeliharaan. Dengan demikian diharapkan kandungan zat gizi dalam tubuh ikan juga tetap terjaga. Dengan latar belakang tersebut akan menimbulkan pertanyaan sejauh mana pengaruh padat tebar terhadap kandungan zat gizi ikan lele yang dipelihara dengan teknologi bioflok? Berdasarkan pada masalah penelitian yang telah diuraikan maka tujuan dari dilakukannya penelitian ini adalah untuk mengukur pengaruh padat tebar terhadap kandungan zat gizi ikan lele yang dipelihara dengan teknologi bioflok.

Penjelasan dari hasil penelitian akan menjadi sebagian informasi ilmiah bagi peneliti dan akademisi yang tertarik pada budi daya ikan lele dengan teknologi bioflok, serta informasi kandungan zat gizi ikan lele hasil budi daya dengan teknologi bioflok. Hipotesis yang dapat dikemukakan untuk penelitian pengaruh padat tebar terhadap kandungan zat gizi ikan lele yang dipelihara dengan teknologi bioflok adalah: Terdapat pengaruh padat tebar terhadap kandungan:

1) kadar air ikan lele.

2) protein ikan lele.

3) karbohidrat ikan lele.

4) total lemak ikan lele.

5) asam lemak jenuh ikan lele.

6) asam lemak tak jenuh tunggal ikan lele.

7) asam lemak tak jenuh jamak ikan lele.

8) total omega-3 ikan lele.

9) total omega-6 ikan lele.

10) total omega-9 ikan lele.

\section{METODE}

Penelitian ini menggunakan tiga perlakuan dengan masing-masing dilakukan tiga kali ulangan. Perlakuan yang diberikan adalah padat tebar yang berbeda. Sebagai acuan dari perlakuan padat tebar tersebut adalah hasil penelitian sebelumnya yaitu menurut Suprapto \& Samtafsir (2013) yang telah mengaplikasikan padat tebar antara 400 sampai dengan $2400 \mathrm{ekor} / \mathrm{m}^{3}$. Rancangan percobaan yang digunakan adalah Rancangan Acak Kelompok (RAK). Pertimbangan dari penggunaan RAK adalah ketidakmampuan mengontrol faktor lingkungan; dalam hal ini arah sinar matahari. Kelompok dibagi menjadi 3, yaitu Kelompok Timur (Kelompok I), Kelompok Tengah (Kelompok II), dan Kelompok Barat (Kelompok III). Dalam tiap-tiap kelompok diberikan 3 perlakuan. Untuk menghindari terjadinya bias keragaman sehingga diperoleh keragaman yang sifatnya alami baik dalam satu perlakuan maupun antar perlakuan dan dapat dihindari keberpihakan pada salah satu perlakuan maka penempatan sembilan kolam (sembilan perlakuan) tersebut dilakukan secara acak (Kusriningrum, 2009). Ada pun perlakuan tersebut adalah sebagai berikut.

1. T1: padat tebar $400 \mathrm{ekor} / \mathrm{m}^{3}$ atau 1000 ekor/kolam.

2. T2: padat tebar $800 \mathrm{ekor} / \mathrm{m}^{3}$ atau 2000 ekor/kolam. 
3. T3: padat tebar $1200 \mathrm{ekor} / \mathrm{m}^{3}$ atau 3000 ekor $/ \mathrm{kolam}$.

Pembesaran ikan lele yang dipelihara dengan teknologi bioflok dilakukan dengan urutan sebagai berikut.

1. Pembuatan kolam terpal dengan ukuran: diameter $2,0 \mathrm{~m} \times$ tinggi $1,0 \mathrm{~m}$.

2. Pengisian air setinggi $80 \mathrm{~cm}$ dan didiamkan selama dua minggu atau sampai terlihat jentik nyamuk hidup. Jentik nyamuk hidup dijadikan sebagai indikator kualitas air yang telah mendukung kehidupan ikan lele.

3. Penumbuhan bioflok dimulai dengan pemberian kapur tohor $100 \mathrm{mg} / \mathrm{m}^{3}$ dan garam krosok (noniodium) $3 \mathrm{~kg}$ per $\mathrm{m}^{3}$ untuk menaikkan $\mathrm{pH}$ hingga berada pada kisaran 7-8. Selanjutnya inokulasi probiotik seperti yang dikemukakan Suprapto \& Samtafsir (2013) yaitu dengan takaran 1,0 g/15 L (kepadatan 1 x 1012 CFU/Colony Forming Unit) dan pemberian molase sebanyak 1,5 ml/15L, dan didiamkan selama dua hari.

4. Fermentasi pakan dilakukan dengan menambahkan $2,0 \mathrm{ml}$ probiotik per kilogram pakan, molase $1,5 \mathrm{ml} / 15 \mathrm{~L}$, dan air $25 \%$ dari berat pakan. Selanjutnya campuran tersebut didiamkan selama 2 hari atau maksimal 7 hari.

5. Pemeliharaan ikan dilakukan selama 8 minggu (atau 60 hari) dan diawali dengan pelepasan benih lele dengan jumlah tiap kolam sesuai dengan perlakuan yaitu untuk tiga kolam pertama 1000 ekor/kolam, tiga kolam kedua 2000 ekor/kolam, dan tiga kolam ketiga 3000 ekor/kolam.

Kegiatan berikutnya yaitu ikan lele yang berumur 60 hari pada tiap-tiap perlakuan tersebut diukur kandungan zat gizinya yang meliputi kandungan:

1) kadar air ikan lele.

2) protein ikan lele.

3) karbohidrat ikan lele.

4) total lemak ikan lele.

5) asam lemak jenuh (saturated fatty acids/SFA) ikan lele.

6) asam lemak tak jenuh tunggal (monounsaturated fatty acids/MUFA) ikan lele.

7) asam lemak tak jenuh jamak (polyunsaturated fatty acids/PUFA) ikan lele.

8) total omega-3: docosahexaenoic (DHA), eicosapentaenoic ((EPA), dan docosapentaenoic (DPA) ikan lele.

9) total omega-6 ikan lele.

10) total omega- 9 ikan lele.

Selanjutnya dilakukan uji statistik menggunakan ANOVA dan uji LSD (Least Significance Different) untuk menentukan hasil perlakuan yang paling baik.

\section{HASIL DAN PEMBAHASAN}

Dalam proses analisisnya, penelitian terkendala oleh ketidakmampuan Laboratorium Penguji dan Kalibrasi Balai Besar Industri Agro (BBIA) Bogor untuk mem-break down kandungan omega-3 menjadi kandungan asam lemak (DHA), (EPA), dan (DPA). Namun demikian BBIA mampu menganalisis kandungan Omega-6 dan Omega-9. 


\section{Kandungan Air}

Air merupakan komponen tubuh termasuk daging ikan yang terbanyak. Kandungannya dapat mencapai kisaran antara 65-80 \%. Jika ikan berlemak rendah maka kadar air pada dagingnya tinggi, akan tetapi jika ikan berlemak tinggi maka kandungan air dagingnya rendah. Selain itu, makin segar daging ikan, makin tinggi kandungan airnya karena sifat daya ikat airnya yang tinggi.

Menurut Astawan (2008), kandungan air daging ikan lele 76\%. Pada penelitian ini menunjukkan bahwa kandungan air berada pada rentang 69,40-71,47\% (Gambar 1). Walaupun hasil analisis statistik menunjukkan bahwa padat tebar tidak berpengaruh nyata terhadap kandungan air ikan lele pada selang kepercayaan 5\% tetapi dari gambar tersebut masih dapat dilihat bahwa untuk perlakuan T3, yaitu padat tebar 3000 ekor per kolam menunjukkan hasil kandungan kadar air tertinggi.

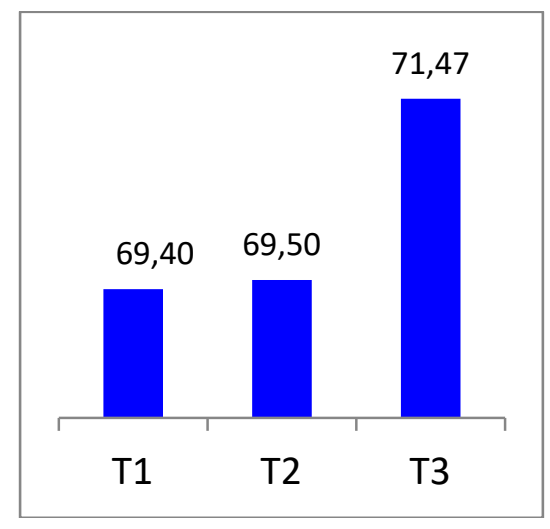

\section{Gambar 1. Rata-rata kandungan air (\%) pada berbagai tingkat padat tebar}

\section{Kandungan Protein}

Ikan merupakan bahan pangan yang mempunyai manfaat besar karena mengandung protein 18-30\%. Protein ikan sangat diperlukan karena mengandung asam amino esensial, nilai biologisnya tinggi (90\%), lebih murah dibandingkan dengan sumber protein lainnya, dan mudah dicerna. Mohammed \& Alim (2012) mengemukakan bahwa dari empat jenis ikan komersial dari Sungai Nil di Sudan mengandung asam amino hingga 19,36\% dengan delapan asam amino esensial (Histidin, Valin,Treonin, Metionin, Lisin, Leusin, Isoleusin, dan Triptofan).

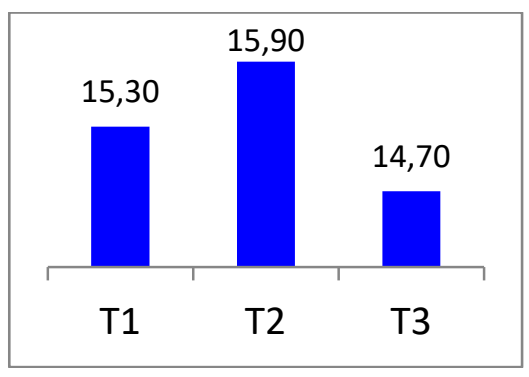

Gambar 2. Rata-rata kandungan protein (\%) pada berbagai tingkat padat tebar 
Jika dilihat dari Gambar 2 nampaknya perlakuan T2 (padat tebar 2000 ekor per kolam) menunjukkan hasil tertinggi untuk kandungan protein. Kenyataan ini kemungkinan disebabkan kandungan flok pada perlakuan T2 lebih tinggi daripada perlakuan lainnya. Walaupun telah diusahakan memberikan tindakan yang sama untuk setiap kolam guna memberikan kepastian kandungan flok yang sama, pada kenyataanya sulit dilakukan di lapangan. Penyebabnya pertumbuhan flok sendiri sangat tergantung pada kondisi lingkungan, salah satunya sinar matahari, sementara letak kolam tidak mungkin diseragamkan posisinya sehingga memperoleh penyinaran matahari yang sama. Hasil analisis statistik menunjukkan bahwa padat tebar ternyata tidak memberikan pengaruh yang nyata terhadap kandungan protein ikan lele pada selang kepercayaan $5 \%$.

\section{Kandungan Karbohidrat}

Fungsi utama karbohidrat (pati, gula) adalah sebagai sumber energi. Fungsi ini tidak unik hanya untuk karbohidrat, karena sebagai sumber energi dapat digantikan oleh protein atau lemak. Karbohidrat dalam daging ikan merupakan polisakarida, yaitu glikogen yang serupa dengan amilum. Pada umumnya kandungan karbohidrat dalam daging ikan sangatlah sedikit, kandungannya kurang dari 1\%. Penelitian yang dilakukan Ramlah, Soekendarsi, Hasyim, \& Hasan (2016) menunjukkan bahwa baik ikan yang berasal dari Danau Mawang maupun Danau Unhas, masing-masing menunjukkan kandungan karbohidrat hanya sebesar $0,32 \%$ dan $0,18 \%$.

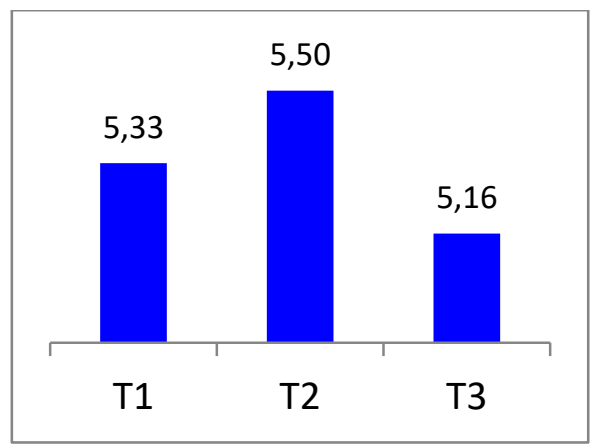

Gambar 3. Rata-rata kandungan karbohidrat (\%) pada berbagai tingkat padat tebar

Kenyataanya, penelitian ini menunjukkan bahwa kandungan karbohidrat ikan lele yang dipelihara dengan teknologi bioflok menunjukkan kandungan karbohidrat kurang lebih lima kali (500\%) lebih tinggi daripada ikan pada umumnya. Dalam penelitian ini diperoleh kandungan karbohidrat berkisar antara 5,16-5,50\% (Gambar 3). Hasil analisis statistik menunjukkan bahwa perlakuan padat tebar tidak berpengaruh nyata terhadap kandungan karbohidrat ikan lele pada selang kepercayaan $5 \%$.

Jika dilihat pada Gambar 3, kecenderungan yang terjadi pada kandungan karbohidrat sejalan/sesuai dengan kandungan protein. Kesesuaian tersebut terlihat pada urutan kandungan dari tertinggi hingga terendah yaitu perlakuan T2 dengan hasil tertinggi kemudian disusul perlakuan T1 dan diikuti perlakuan T3 sebagai yang terendah.

Dikarenakan kandungan karbohidrat tertinggi terjadi pada perlakuan T2, dimana hal ini juga terjadi pada kandungan protein (Gambar 2) maka kemungkinan flok yang terbentuk paling bagus 
adalah pada kolam dengan perlakuan T2. Penyebab dari pembentukan flok tertinggi pada perlakuan T2 kemungkinan disebabkan letak kolam yang strategis untuk pembentukan flok. Strategis di sini dalam arti letak kolam dipengaruhi hal-hal baik yang mendukung pertumbuhan flok dalam kolam.

\section{Kandungan Lemak Total}

Winarno (1993) menyatakan bahwa berdasarkan kandungan lemaknya, ikan terbagi menjadi 3 golongan yaitu: ikan dengan kandungan lemak rendah (kurang dari $2 \%$ ), ikan dengan kandungan lemak sedang (2-5\%) dan ikan dengan kandungan lemak tinggi (4-5\%). Sikorski \& Kolakowska (2003) menjelaskan penggolongan berdasarkan kandungan lemaknya adalah kurang dari $2 \%$ termasuk golongan ikan berlemak rendah, 2 sampai dengan $7 \%$ termasuk ikan berlemak sedang (medium), 7 sampai 15\% termasuk golongan ikan berlemak, dan lebih besar daripada 15\% termasuk ikan berlemak tinggi. Dalam penggolongan ini lele termasuk ikan berlemak tinggi (> 15\%).

Hasil penelitian menunjukkan kandungan lemak ikan lele yang dipelihara dengan teknologi bioflok rata-rata berkisar antara 6,73-7,98\% (Gambar 4). Dengan demikian baik mengikuti penggolongan ikan berdasarkan kandungan lemak yang umum digunakan maupun mengikuti penggolongan Sikorski \& Kolakowska (2003), kandungan lemak ikan lele hasil penelitian tergolong di atas medium.

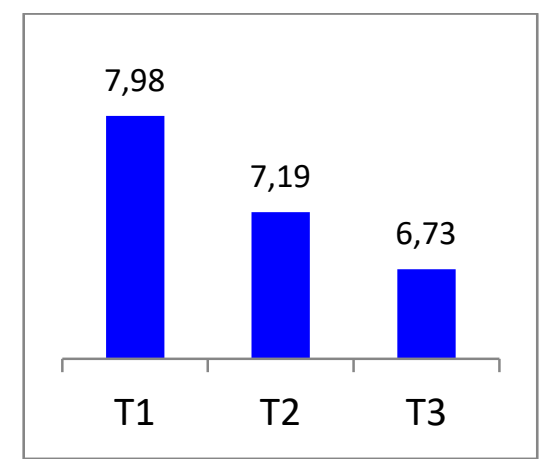

Gambar 4. Rata-rata kandungan lemak total (\%) pada berbagai tingkat padat tebar

Berdasarkan hasil analisis statistik yang menunjukkan bahwa perlakuan padat tebar tidak berpengaruh nyata terhadap kadar kadar lemak ikan lele pada selang kepercayaan $5 \%$, Gambar 4 masih dapat menunjukkan perbedaan kandungan lemak pada ikan lele. Seperti yang dikemukakan oleh Sikorski \& Kolakowska (2003) bahwa kandungan lemak dan kandungan air sangat bertolak belakang. Jika kandungan air tinggi maka kandunga air rendah, dan sebaliknya. Pernyataan tersebut sesuai dengan fakta yang diperolah dalam penelitian ini. Dari Gambar 1 dan 4 jika dilihat kecenderungan kandungan lemak dan air untuk perlakuan T1, T2, dan T3 terlihat kesesuaian tersebut.

\section{Kandungan Asam Lemak}

Kelompok asam lemak utama meliputi asam lemak jenuh (SFA), asa lemak tak jenuh tunggal (MUFA), dan asam lemak tak jenuh jamak (PUFA). Proporsi masing-masing kelompok asam lemak terhadap lemak total dalam daging ikan berbeda-beda. Perbedaan ini sangat tergantung pada 
kandungan lemak total atau golongan ikan berdasarkan kandungan lemaknya, selain itu dapat juga dipengaruhi oleh faktor-faktor biologis. Pada umumnya kandungan asam lemak secara individu pada daging ikan tersusun atas SFA sekitar 30\%, 20\% hingga lebih dari 40\% MUFA, dan 20\% hingga lebih dari 40\% PUFA (Sikorski \& Kolakowska, 2003). Artinya proporsi terendah adalah kandungan SFA.

Hasil yang diperoleh dari penelitian ini menunjukkan hal yang berbeda untuk semua perlakuan. Proporsi terhadap asam lemak secara individu justru diduduki SFA (sekitar 43\%), kemudian disusul MUFA sekitar 32\%, dan yang paling kecil PUFA (sekitar 23\%). Perbedaan ini kemungkinan disebabkan oleh cara pemeliharaannya. Dalam memperolah pakan, ikan yang dipelihara di kolam tanah tentunya berbeda dengan ikan yang dipelihara di kolam terpal. Apalagi jika dibandingan dengan ikan yang hidup di alam bebas. Namun demikian, dalam hal ini masih diperoleh hasil yang baik, yaitu kandungan kelompok asam lemak yang baik untuk kesehatan (asam lemak tak jenuh) masih lebih tinggi daripada kelompok asam lemak jenuh untuk semua perlakuan.

Hasil yang diperoleh dari penelitian ini untuk kandungan SFA, MUFA, da PUFA disajikan secara berurutan pada Gambar 5, 6, dan 7. Hasil analisis statistik terhadap ketiga kelompok asam lemak tersebut menunjukkan hasil yang tidak nyata terhadap perlakuan berbagai padat tebar pada tingkat kepercayaan $5 \%$. Dari ketiga gambar tersebut juga terlihat persamaan bahwa kandungan kelompok asam lemak tertinggi adalah perlakuan T1 (padat tebar 1000 ekor per kolam), kemudian disusl T2 (padat tebar 2000 ekor per kolam), dan yang terkecil adalah perlakuan T3 (padat Tebar 3000 ekor per kolam).

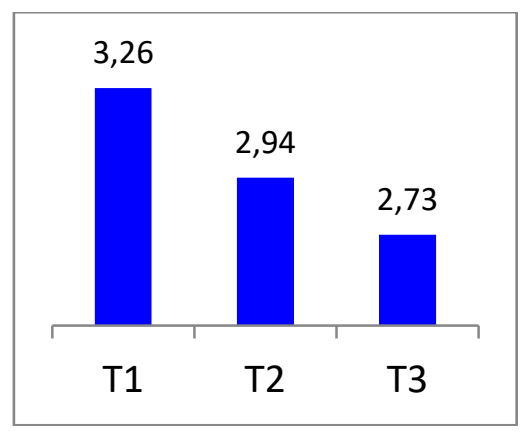

Gambar 5. Rata-rata kandungan asam lemak jenuh (Saturated Fatty Acids/SFA) (\%) pada berbagai tingkat padat tebar

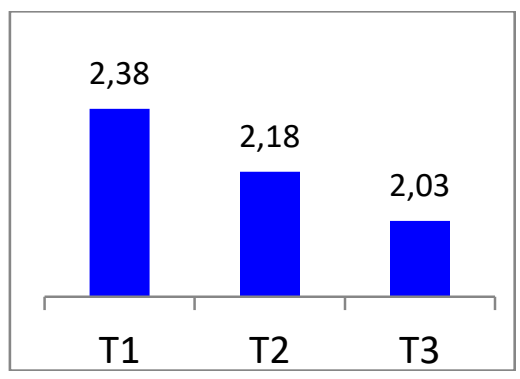

Gambar 6. Rata-rata kandungan asam lemak tak jenuh tunggal tunggal (Monounsaturated Fatty Acids/MUFA) (\%) pada berbagai tingkat padat tebar 


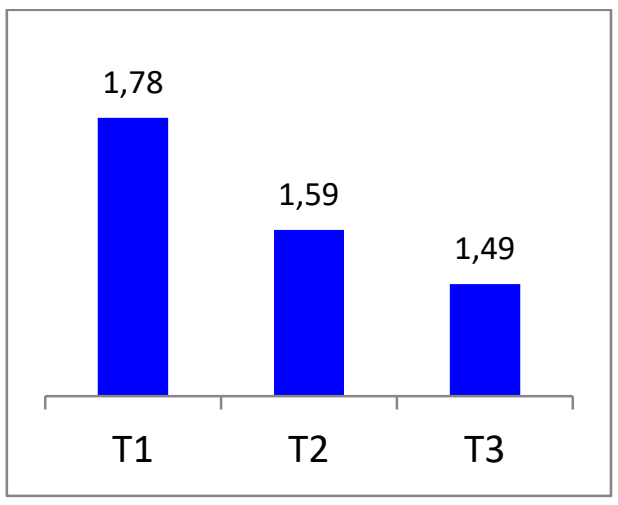

Gambar 7. Rata-rata kandungan asam lemak tak jenuh jamak (Polyunsaturated Fatty Acids/PUFA) (\%) pada berbagai tingkat padat tebar

Kandungan Asam Lemak Tak Jenuh Jamak (Polyunsaturated Fatty Acids/PUFA)

PUFA terdiri dari asam lemak omega-3 (n-3), omega-6 ( -6 ). Omega-3 dianggap sebagai salah satu asam lemak esensial, yang berarti bahwa substansi tersebut dibutuhkan tubuh agar tetap sehat, tetapi tubuh tidak mampu memproduksinya sendiri. Asam lemak n-3 merupakan kelompok Long-Chain Polyunsaturated Fatty Acid (LCPUFA) mempunyai peran penting dalam perkembangan otak dan fungsi penglihatan (Hornstra 2000 dalam Thoha, 2004). Seperti halnya asam lemak n-3, asam lemak n-6 juga berperan sebagai asam lemak otak. Kedua asam lemak menghasilkan tiga bentuk asam lemak n-3 yaitu asam a-linolenat, EPA dan DHA (Elvevoll 2000 dalam Thoha, 2004).

Sedangkan asam lemak oleat sering disebut sebagai omega-9 (n-9) dan termasuk Monounsaturated Fatty Acid (MUFA) mempunyai peranan cukup penting dalam kesehatan. Menurut Pranoto (2006), asam lemak omega-9 memiliki daya perlindungan yang mampu menurunkan LDL dan meningkatkan HDL. Asam lemak ini dan asam lemak omega-3 juga memiliki potensi untuk menghadang produksi senyawa eikosanoid.

Kuantitas asam lemak pada ikan tergantung kepada jenis spesies dan habitat (Haliloglu, Bayir, Sirkecioglu, 2004). Selain itu, variasi nilai asam lemak dapat disebabkan oleh jenis makanan, salinitas, usia, dan jenis kelamin (Satue, Lopez, \& Agramont, 1994).

Hasil yang diperoleh dari penelitian ini tentang kandungan asam lemak omega-3 disajikan pada Gambar 8. Pada gambar tersebut terlihat bahwa kecenderungan kandungan omega-3 terlihat berbeda dengan asam lemak yang lain untuk tiap-tiap perlakuan yang diberikan. Kandungan asam lemak tertinggi berada pada perlakuan T3, kemudian diikuti T1, dan yang terakhir T2.

Asam lemak omega-6 adalah asam lemak biologis yang sangat diperlukan yang berasal dari asam lemak esensial yang mengandung 18 atom karbon dengan dua ikatan kimia ganda, yang dikenal sebagai asam linoleat. Hasil yang diperoleh dari penelitian ini tentang kandungan asam lemak omega-6 disajikan pada Gambar 9. Pada gambar tersebut terlihat bahwa kandungan asam lemak omega-6 memiliki kecenderungan yang sama dengan asam lemak yang lain untuk tiap-tiap perlakuan yang diberikan. Kandungan asam lemak tertinggi berada pada perlakuan $\mathrm{T} 1$, kemudian diikuti T2, dan yang terkecil adalah T3. 


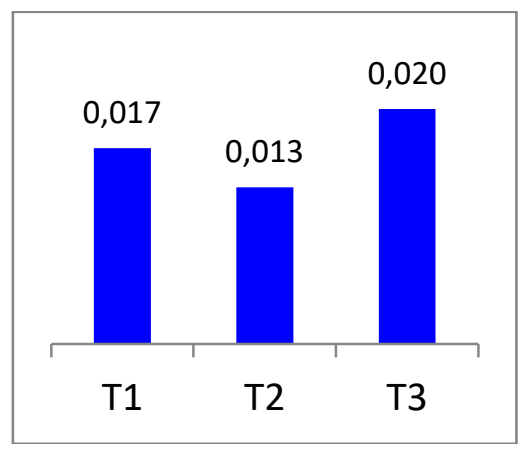

Gambar 8. Rata-rata kandungan omega-3 (\%) pada berbagai tingkat padat tebar

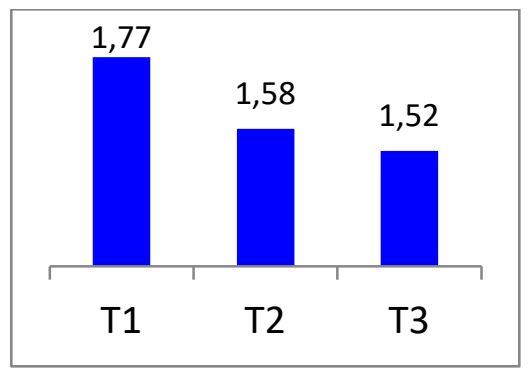

\section{Gambar 9. Rata-rata kandungan omega $6(\%)$ pada berbagai} tingkat padat tebar

Omega-9 merupakan asam lemak tak jenuh, dikenal sebagai asam oleat. Asam lemak ini diproduksi oleh tubuh namun akan lebih berkhasiat bila diperoleh dari makanan. Hasil yang diperoleh dari penelitian ini tentang kandungan asam lemak omega-9 disajikan pada Gambar 10. Pada gambar tersebut terlihat bahwa kandungan asam lemak omega-9 memiliki kecenderungan yang sama dengan asam lemak yang lain untuk tiap-tiap perlakuan yang diberikan. Kandungan asam lemak tertinggi berada pada perlakuan T1, kemudian diikuti T2, dan yang terkecil adalah T3.

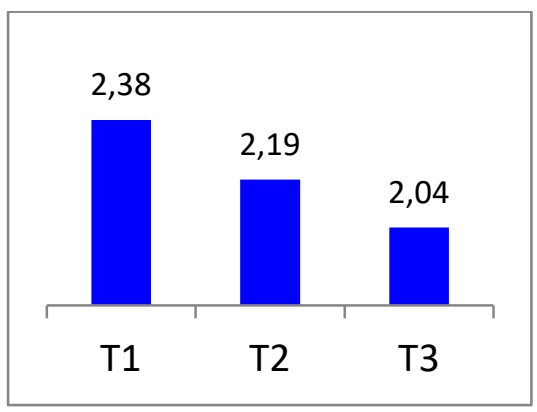

Gambar 10. Rata-rata Kandungan Omega-9 (\%) pada Berbagai Tingkat Padat Tebar 
Walaupun tiap perlakuan untuk kandungan omega 3, 6, dan 9 masih dapat dilihat perbedaannya namun hasil analisis statistik menunjukkan bahwa perlakuan padat tebar tidak berpengaruh nyata terhadap kandungan omega-3, 6, dan 9 ikan lele pada selang kepercayaan 5\%.

\section{SIMPULAN}

Perlakuan padat tebar lele yang dipelihara dengan teknologi bioflok pada selang kepercayaan $5 \%$ tidak memberikan pengaruh yang nyata terhadap kandungan zat gizinya. Dalam kaitannya dengan urban farming disarankan dilakukan penelitian lanjutan aquaponic (berupa tumpangsari antara bioflok dengan tanaman pangan).

\section{REFRENSI}

Anonim. (2013). Budidaya ikan lele teknologi bioflok - Efisiensi pakan. (Booklet). Jakarta: Direktorat Usaha Budidaya, Direktorat Jenderal Perikanan Budidaya.

Astawan, M. (2008). Jeroan bagi kesehatan. Jakarta: PT. Dian Rakyat.

Haliloglu, H.I.; Bayir, A.; Sirkecioglu, A.N. (2004). Comparison of fatty acid composition in some tissues of rainbow trout (Oncorhynchus Mykiss) living in seawater and freswater. Food Chemistry, V.86, P.55-59, 2004.

Kusriningrum. (2009). Dasar perancangan percobaan dan rancangan acak lengkap. Surabaya: Universitas Airlangga.

Meliala, E.R.S. (2009). Konsumsi ikan dan kontribusinya terhadap kebutuhan protein pada keluarga nelayan di lingkungan IX Kelurahan Labuhan Deli Kecamatan Medan Marelan. Skripsi. Fakultas Kesehatan Masyarakat Universitas Sumatera Utara.

Mohammed, M.O., Alim, D.I. (2012). Amino acids contents of four commercial Nile fishes in Sudan. African Journal of Environmental Science and Technology, Vol. 6(2), pp. 142-145, February 2012.

Pranoto T. (2006). Asam lemak tak jenuh-penurun risiko penyakit jantung koroner. Fakultas Kesehatan Masyarakat. Universitas Indonesia.

Ramlah, Soekendarsi, E., Hasyim, Z., \& Hasan, M.S. (2016). Perbandingan kandungan gizi ikan nila oreochromis niloticus asal Danau Mawang Kabupaten Gowa dan Danau Universitas Hasanuddin Kota Makassar. Jurnal Biologi Makassar (Bioma), Volume 1, Nomor 1, 2016.

Sari, R.P. (2015). Subtitusi tepung pisang awak (Musa paradisiaca var awak) dan ikan lele dumbo (Clarias gariepinus) dalam pembuatan biskuit serta uji daya terimanya. Skripsi. Medan, Fakultas Kesehatan Masyarakat Universitas Sumatera Utara.

Satue MT, Lopez MC, \& Agramont A. (1994). Fatty acid composition of trout oil. Food chemistry 50: 363-365.Sudarmadji S, Suhardi BH. 1989. Analisa Bahan Makanan dan Pertanian. Yogyakarta: Penerbit Liberty Yogakarta bekerjasama dengan PAU Pangan dan Gizi, UGM.

Sikorski, Z. E. \&. Kolakowska (2003). Chemical and functional properties of food lipids. United States of America: CRC PRESS.

Suprapto, N.S., \& Samtafsir, L.S. (2013). Bioflok - Rahasia sukses teknologi budidaya lele. Depok: AGRO-165.Thoha. (2004). Asam lemak esensial untuk optimalisasi fungsi otak balita [tesis]. Bogor: Program Pasca Sarjana, Institut Pertanian Bogor. 
Thoha. (2004). Asam lemak esensial untuk optimalisasi fungsi otak balita [tesis]. Bogor: Program Pasca Sarjana, Institut Pertanian Bogor.

Winarno, F. G. (1993). Pangan Gizi, Teknologi dan Konsumen. Gramedia Pustaka Utama. Jakarta. Yuniartik, M., Hariati, A.M., \& Fadjar, M. (2015). Effect of biofloc on feed efficiency and growth of pacific white shrimp, litopenaeus vannamei (Boone, 1932). J. Life Sci. Biomed, 5(3): 70-74, May 30, 2015. ISSN 2251-9939. 